\title{
Development of Garcinia Atroviridis Capsule Towards Safe, Quality and Efficacious Product
}

\author{
Noor Rasyila $\mathrm{MN}^{1^{*}}$, Zamree $\mathrm{MS}^{2}$, Nurhazwani $\mathrm{MH}^{1}$, Nor Azah $\mathrm{MA}^{1}$, Tan $\mathrm{AL}^{3}$, \\ Norulaiman $\mathbf{Y}^{1}$, Adib Zubaidi $\mathbf{R}^{2}$, Mohd Hafidz Hadi $\mathbf{A}^{4}$, \\ Mohd Faizal $A^{1}$, Juliza $M^{5} \&$ Rohana $S^{5}$ \\ ${ }^{1}$ Herbal Products Development Programme, Natural Products Division, \\ ${ }^{2}$ Herbal Technology Centre, Innovation and Commercialization Division, \\ ${ }^{3}$ Bioresources Programme, Natural Products Division, \\ ${ }^{4}$ Phytochemistry Programme, Natural Products Division, \\ ${ }^{5}$ Bioactivity Programme, Natural Products Division, Forest Research Institute Malaysia, \\ Kepong, Selangor \\ *Corresponding author: rasyila@frim.gov.my
}

\begin{abstract}
Malaysia is one of the countries that has a rich diversity of underutilized fruits that grow wild in the region of Peninsular Malaysia, Sabah and Sarawak. One of them is Garcinia atroviridis or Asam gelugor. The crude extracts of the leaf and fruit possess predominantly antibacterial, antifungal, free-radical scavenging, anti-inflammatory activity and also reduces body weight. The use of Garcinia has been rapidly growing in the United States due to the desire of people to lose weight. Losing weight can be a challenge for many people. While most experts agree that a combination of proper diet and exercise is the best way to go, there are things that can be done to speed up the process. Herbs are good for speeding up the metabolism, aiding in digestion and energizing, so the output will be more intensity. Previous study found that aqueous extract of Garcinia atroviridis fruit significantly reduced the body weight of rats. Due to its potentiality to be developed as pharmaceutical and herbal medicine, this study was conducted to enhance the quality of herbal products produced through the research and development offered by FRIM. FRIM is very much concerned and aware of the implementation of three main aspects which are quality, safety and efficacy that is often emphasized by the Ministry of Health Malaysia $(\mathrm{MOH})$ under the Food Safety \& Quality Division and the National Pharmaceutical Regulatory Agency (NPRA) on herbal products marketed. The product development for formulating and producing capsule activities are initiated by looking into ethno-botanical information of herbal used, chemical and biological analysis, formulation of products and product performance and lastly IPQC testing and safety study. It is hoped that this study will produce herbal products with better quality as well as complying with the standards and able to penetrate into the global market.
\end{abstract}

Keywords Garcinia atroviridis, product development, capsule

\section{INTRODUCTION}

The Garcinia atroviridis tress is a native of Peninsular Malaysia, Thailand, Myanmar and India. It is extensively cultivated in Myanmar and in Southern Thailand. In Malaysia, the young tender leafy shoots are eaten fresh or cooked as "ulam" or as a sour relish [1]. Green young fruits turn bright yellow when ripe and often separate off into pegs or segments. A mature fruit can weigh up to $2 \mathrm{~kg}$. Traditionally, $G$. atroviridis fruit are used after confinement by mixing the fruit with a lotion made with vinegar and the juice from the leaves is also used after childbirth. The dried fruit slices are used to give acidity to cooked dishes in place of tamarind or lemon. The dried rind is also used in herbal health teas. In Thailand, the demand for G. atroviridis as health food is steadily increasing. Slices of dry fruit are sold $5-7.5$ US dollars per kg throughout the year [2]. 
G. atroviridis fresh fruits and extract (solvent and aqueous), supported by experimental data- showed potential in biological and pharmacological activities such as anti-atherosclerotic, antibacterial, antifungal, anti-inflammatory, antioxidant, antitumor and cytotoxic activities [3]. This plant was reported contain hydroxycitric acid (HCA), a bioactive compound that acts as a potent inhibitor of fatty acid and cholesterol synthesis by inhibiting lipogenesis, the metabolic process that changes carbohydrate into fat and fruiting acids such as citric acid, tartaric acid, malic acid and ascorbic acid that have an antioxidant activity. Hydroxycitric acid is found in the fruits and in the rind of certain Garcinia fruits. (-)-Hydroxycitric acid, or (-)-HCA, is the principal acid of fruit rinds of G. cambogia, G. indica and G. atroviridis [4]. Previous study found that the water extract of $G$. atroviridis fruit significantly reduced the body weight of rats, supporting evidence for the usage of this plant in formulating weight-reducing herbal-based products [5]. Clinical study done towards 25 obese Thai women by Roongisuthipong et al. (2007) showed that triceps skinfold, biceps skinfold, subscapular skinfold, suprailiac skinfold, upper arm circumference, percentage of the body fat and body fat weight (kg) were reduced. G. atroviridis is also found to reduce blood pressure in rats [4].

The product development for formulating and producing capsule activities are initiated by looking into ethno-botanical information of herbal used, chemical and biological analysis, formulation of products and product performance and lastly IPQC testing and safety study. This study was conducted to enhance the quality of herbal products produced through the research and development offered by FRIM due to its potentiality to be developed as pharmaceutical and herbal medicine. The $\mathrm{R} \& \mathrm{D}$ activities conducted by FRIM include three main aspects (quality, safety and efficacy) that are often emphasized its implementation by the Ministry of Health under the Food Safety \& Quality Division and National Pharmaceutical Regulatory Agency (NPRA) on herbal products development to be developed and marketed.

It is hoped that this study will produce herbal products with better quality as well as complying with the standards and able to penetrate into the global market.

\section{EXPERIMENTAL}

\section{Sample preparation}

Samples of fresh G. atroviridis fruits were collected from Taman Herba Ethno Resources Sdn, Bhd., Bukit Gantang Perak. The raw materials were sliced, washed and dried in $55^{\circ} \mathrm{C}$ oven. The dried fruit were ground to a fine powder and kept in an air tight container for extraction process.

\section{Authentication process}

Samples consisting of twigs, leaves, flowers and fruit were collected in three replicates and sent for authentication process.

\section{Extraction}

Based on the previous study, an aqueous extract were prepared by using optimized temperature and incubation time; and were concentrated and ready for freeze drying [5].

\section{Safety test of raw material}

\section{a. Microbial load}

Microbial quality of Garcinia atroviridis; raw material, extract and finished product were determined by microbial contamination test based on British Pharmacopoeia [11]. Enumeration of microbial count and detection of the absence or limited occurrence of selected microbial species; namely Escherichia coli, Salmonella spp., Staphylococcus aureus, Pseudomonas aeruginosa, Candida albicans, and bile tolerant gram negative bacteria were carried out. 


\section{b. Heavy metal analysis}

The concentrations of heavy metals in sample were determined by using Perkin Elmer Model Analyst 600 Atomic Absorption Spectrometry (AAS). Graphite Furnace Atomic Absorption Spectrometry (GFAAS) was used to measure lead, arsenic and cadmium metals, while Flow Injection for Atomic Spectroscopy System (FIAS 100) was used to determine mercury metals. This AAS system is equipped with hollow cathode lamp (HCL) for cadmium and electrode less discharge lamp (EDL) for lead, mercury and arsenic as the source of the energy.

Heavy metal concentration in sample must comply and did not exceed maximum limit as regulated by National Pharmaceutical Regulatory Agency (NPRA) in Drug Registration Guidance Document (DRGD), First Edition, January 2013, Revised January 2016 [6]. The maximum limits for heavy metals are as follows;

Table 1 The maximum limit for heavy metals in Drug Registration Guidance Document (DRGD), First Edition, January 2013, Revised January 2016

\begin{tabular}{lc}
\hline Heavy metal elements & Maximum limit (mg/kg or $\mathbf{~ m g / l i t r e ~ o r ~ p p m ) ~}$ \\
\hline Lead & NMT 10.0 \\
Cadmium & NMT 0.3 \\
Mercury & NMT 0.5 \\
Arsenic & NMT 5.0 \\
\hline
\end{tabular}

*NMT $=$ Not more than

\subsection{Phytochemical screening}

\section{a. Alkaloid testing: Mayer's test}

The sample was macerated in chloroform followed by addition of ammoniacal chloroform. The mixture was then treated with 10\% sulfuric acid and tested with Mayer's reagent. Formation of white precipitates indicates the presence of alkaloids.

\section{b. Saponin testing}

The methanol extract of sample was mixed with distilled water in a test tube. The formation of honeycomblike froth for at least 15 minutes indicates the presence of saponins.

\section{c. Triterpenoids and Steroids testing: Liebermann-Burchard's test}

The chloroform extract of sample was tested using Liebermann-Burchard reagent. Formation of reddish pink colour indicates the presence of triterpenoids. On the other hand, formation of greenish colour indicates the presence of steroids.

\section{d. Flavonoids testing}

The chloroform extract of sample was dissolved in ether and shaken in 10\% ammonia solution. Formation of yellow or orange colour in ammonia layer indicates the presence of flavonoids.

\section{e. Tannin testing}

The methanolic extract of sample was mixed with $1 \%$ ferric chloride solution. The colour changes and formation of blue black colour precipitate indicated of hydrolysable tannins. On the other hand, formation of brownish green colour precipitate indicates condensed tannins.

\subsection{Bioactivities and safety evaluation}




\section{a. Antioxidant and toxicity study}

The samples are tested against three (3) antioxidant bioassays: i. Xanthine/ Xanthine Oxidase Superoxide Scavenging System: The assay evaluates the scavenging activity of the sample on superoxide free-radical anions ii. DPPH Radical Scavenging Assay: The assay evaluates the reducing activity of the sample that determines its antioxidant potential (AOP) iii. TPC analysis: Total Phenolic Content Analysis indicates the amount of Polyphenols in the sample tested equivalent to Gallic acid standard. Cytotoxicity was monitored by 3-(4, 5-dimetyl-2-thiazolyl)-2, 5-diphenyl-2H-tetrazolium bromide (MTT) assay (Mosmann, 1983). The cells used for the testing were Vero and WRL-68; which are kidney- and hepatic-like cell lines, respectively. The assay measures the reduction potential of the cells using colorimetric reaction, an indication of viable cells, I particular and viable mitochondrial system. Dose-response curves were generated for each test substance and the median inhibitory concentration $\left(\mathrm{IC}_{50}\right)$ determined by non-linear regression.

\subsection{Product formulation, performance study and safety study}

Extract of G. atroviridis was formulated based on the ratio or the quantity of the active ingredient dosage and excipient required. Product performance testing including uniformity and disintegration testing as well as physical characteristics such as moisture content was also conducted. The prototyped capsule product will again be tested with heavy metal and microbial testing to ensure that the product is safe.

\section{RESULTS AND DISCUSSION}

The species was identified by FRIM's Botanist as Garcinia atroviridis Griff. ex T. Anderson Clusiaceae (Guttiferae) family.

The test results displayed that the heavy metal and microbial load test of raw material is within the safety limit (Table 2 and 3)

\begin{tabular}{|c|c|c|c|c|}
\hline \multicolumn{5}{|c|}{ Table 2 : HEAVY METAL ANALYSIS : RAW MATERIAL } \\
\hline Test & Method of Analysis & Specification & Results & Remark \\
\hline Lead $(\mathrm{Pb})$ & \multirow[b]{2}{*}{ BS EN14084 : 2003} & $\leq 10.00 \mathrm{mg} / \mathrm{kg}$ & $0.5 \mathrm{mg} / \mathrm{kg}$ & Comply \\
\hline Cadmium (Cd) & & $\leq 0.30 \mathrm{mg} / \mathrm{kg}$ & $0.08 \mathrm{mg} / \mathrm{kg}$ & Comply \\
\hline Mercury (Hg) & \multirow{2}{*}{$\begin{array}{l}\text { In-house method } \\
\text { (AK(51).PPH.(NPQC-LB).01) }\end{array}$} & $\leq 0.50 \mathrm{mg} / \mathrm{kg}$ & $\begin{array}{c}\mathrm{ND}(<0.01) \\
\mathrm{mg} / \mathrm{kg}\end{array}$ & Comply \\
\hline Arsenic (As) & & $\leq 5.00 \mathrm{mg} / \mathrm{kg}$ & $1.69 \mathrm{mg} / \mathrm{kg}$ & Comply \\
\hline
\end{tabular}

\begin{tabular}{|c|c|c|c|c|}
\hline \multicolumn{5}{|c|}{ Table 3 : MICROBIAL LOAD TEST : RAW MATERIAL } \\
\hline Test & $\begin{array}{l}\text { Method of } \\
\text { Analysis }\end{array}$ & Specification & Results & Remark \\
\hline $\begin{array}{l}\text { Total Aerobic } \\
\text { Microbial Count }\end{array}$ & \multirow{4}{*}{$\begin{array}{l}\text { British } \\
\text { Pharmacopeia } \\
2011\end{array}$} & $\begin{array}{c}\leq 5 \times 10^{7} \mathrm{cfu} / \mathrm{g} \\
@ \mathrm{cfu} / \mathrm{ml}\end{array}$ & $<10 \mathrm{CFU} / \mathrm{g}$ & Comply \\
\hline $\begin{array}{l}\text { Total Yeast \& } \\
\text { Moulds Count }\end{array}$ & & $\begin{array}{c}\leq 5 \times 10^{5} \mathrm{cfu} / \mathrm{g} \\
@ \mathrm{cfu} / \mathrm{ml}\end{array}$ & $10 \mathrm{CFU} / \mathrm{g}$ & Comply \\
\hline $\begin{array}{l}\text { Escherichia coli (E. } \\
\text { Coli) }\end{array}$ & & $\begin{array}{c}\leq 10^{3} \mathrm{cfu} / \mathrm{g} @ \\
\mathrm{cfu} / \mathrm{ml}\end{array}$ & $<10 \mathrm{PN} / \mathrm{g}$ & Comply \\
\hline Salmonella spp. & & Absent & Absent & Comply \\
\hline
\end{tabular}


The aim of phytochemical testing is to detect some of the important phytochemical constituents that usually exhibit biological activities such as alkaloids, saponins, flavonoids, tannins, triperpenes and steroids. The chemical profiling/ fingerprint showed that extract of G. atroviridis only contain 3+ Flavonoids and 1+ Condensed tannins based on 100g of sample (Table 4).

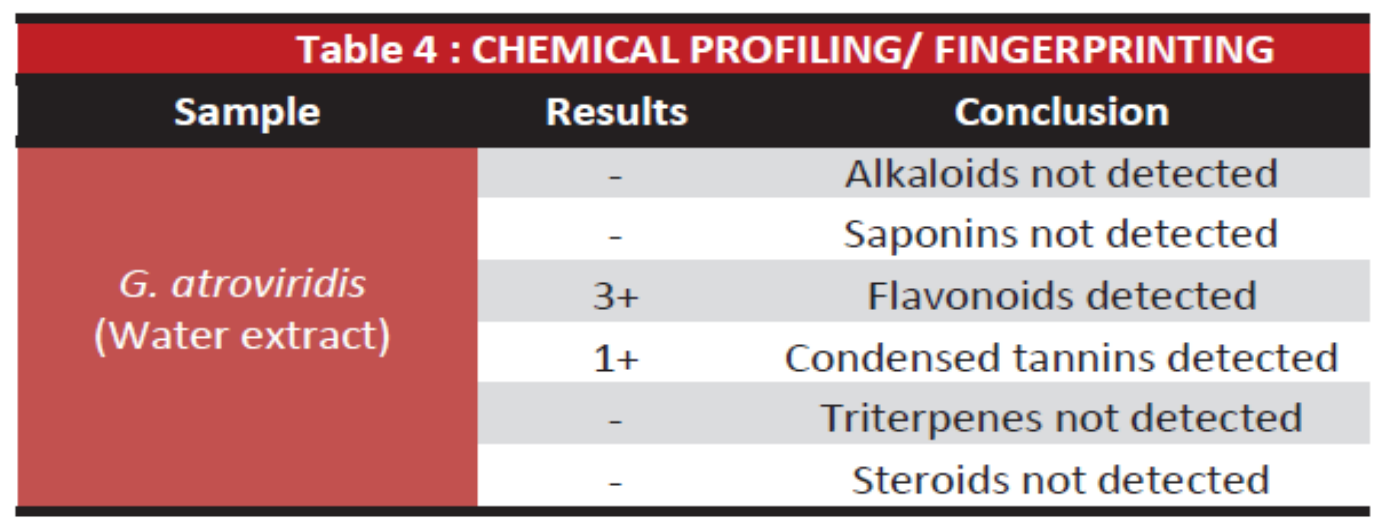

$1+$ week colour; $2+$ mild colour; $3+$ strong colour

Antioxidant test of $G$. atroviridis extract revealed that the extracts showed low activity against the Xanthine / Xanthine Oxidase Superoxide Scavenging System, low inhibition by DPPH Radical Scavenging assay and low TPC value. Free radicals are produced during aerobic metabolism where oxygen is used to oxidize the food to produce energy. Free- radicals are toxic by-products from normal biochemical processes of the body cells and can create chain reactions, which cell membrane damage, DNA mutation, lipid and protein damage, immune cell damage and cell death. Thus, samples that are found to inhibit the activity of free radicals could possibly contain natural antioxidants that can help enhance the immune-system, prevent disease and improve general health and life quality.

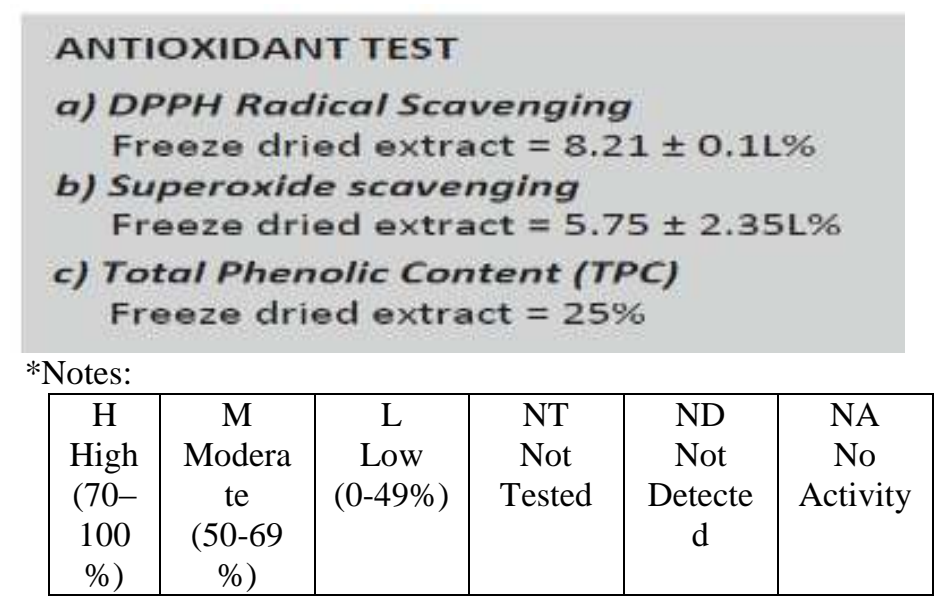

Toxicity studies are conducted to determine the toxic profile of a substance. This is important because substance that has therapeutic potentials may also cause adverse events. The measurement on the degree of a substance having destructive action on cells is known as cytotoxicity testing. Cytotoxicity test showed that the results of IC50 high viability and prove the G. atroviridis extract is less toxic (Table 5). Cytotoxic effects are related to the sample's therapeutic dose. The sample is considered safe due to the therapeutic dose is higher than the cytotoxic value. 

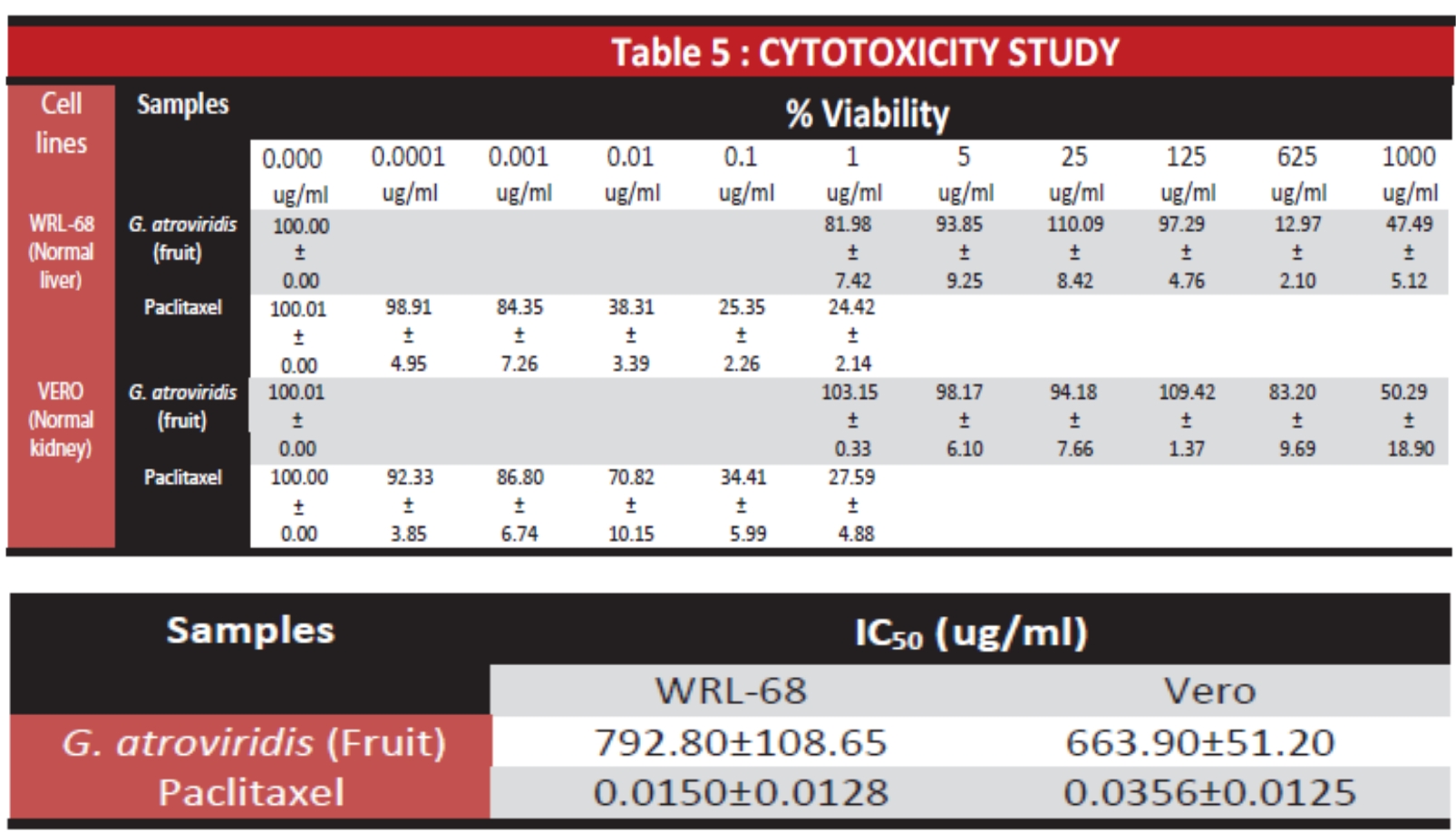

Product performance study (Table 5), the G. atroviridis capsule disintegrates less than 30 minutes which is 6 min 18 sec., which complies with the standard as outlined by National Pharmaceutical Regulatory Agency (NPRA). The capsule also complies with the safety standards for heavy metal analysis \& microbiol load test. (Table 6-7).

\begin{tabular}{|c|c|c|c|c|}
\hline \multicolumn{5}{|c|}{ Table 5 : PRODUCT PERFORMANCE STUDY } \\
\hline Test & Method of Analysis & Specification & Results & Remark \\
\hline $\begin{array}{l}\text { Moisture } \\
\text { content }\end{array}$ & $\begin{array}{l}\text { In House Method } \\
\text { [Flle2, sop Production } \\
\text { Department) }\end{array}$ & $\leq 10 \%$ & $5.09 \%$ & Comply \\
\hline Disintegration & $\begin{array}{l}\text { Ph. Eur } 7.0 \\
04 / 2011: 20901\end{array}$ & $\leq 30$ minutes & $\begin{array}{c}6 \min 18 \\
\mathrm{sec}\end{array}$ & Comply \\
\hline
\end{tabular}

\begin{tabular}{|c|c|c|c|c|}
\hline \multicolumn{5}{|c|}{ Table 6 : HEAVY METAL ANALYSIS : RAW MATERIAL. } \\
\hline Test & Method of Analysis & Specification & Results & Remark \\
\hline Lead (Pb) & In-house method & $\leq 10.00 \mathrm{mg} / \mathrm{kg}$ & $\begin{array}{c}\mathrm{ND}(<0.01) \\
\mathrm{mg} / \mathrm{kg}\end{array}$ & Comply \\
\hline Cadmium (Cd) & [AX(152],PPH.(NPQC-LB],01] & $\leq 0.30 \mathrm{mg} / \mathrm{kg}$ & $\begin{array}{c}\mathrm{ND}(<0.01) \\
\mathrm{mg} / \mathrm{kg}\end{array}$ & Comply \\
\hline Mercury (Hg) & $\begin{array}{l}\text { In-house method } \\
\text { (AK(51):PPH.|NPRCAB),01] }\end{array}$ & $\leq 0.50 \mathrm{mg} / \mathrm{kg}$ & $\begin{array}{c}\mathrm{ND}(<0.01) \\
\mathrm{mg} / \mathrm{kg}\end{array}$ & Comply \\
\hline Arsenic (As) & 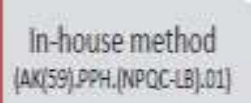 & $\leq 5.00 \mathrm{mg} / \mathrm{kg}$ & $1.69 \mathrm{mg} / \mathrm{kg}$ & Comply \\
\hline
\end{tabular}




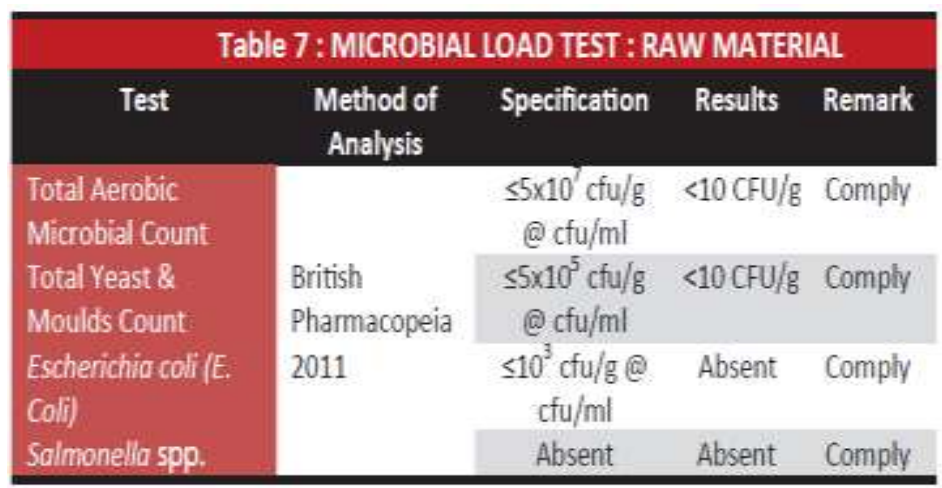

\section{CONCLUSION}

The plant material and extracts of $G$. atroviridis become popular commercial products, even being available through Internet markets worldwide, making the active components from this plant an important issue to be understood. The product development for formulating and producing capsules activities is initiated by looking into ethno-botanical information of herbal used, chemical \& biological analysis, formulation of product \& product performance and lastly IPQC testing \& safety study in conformity with the standards set for quality control testing of the finished product. It is hoped that this study will produce herbal products with better quality as well as complying with the standards and able to penetrate into the global market.

\section{ACKNOWLEDGEMENT}

The authors would like to express their gratitudes to MARA for the funding of Projek Teknousahawan Teknologi Herba, Natural Products Division and FRIM for their technical support.

\section{REFERENCES}

[1] Mackeen, M. M., Ali, A.M., El-Sharkawy, S. H., Salleh, K.M., Lajis., Kawazu. (1997). Antimicrobial andcytotoxic properties of some Malaysian traditional vegetables (ulam). International Journal of Pharmacognosy 35, 174-178.

[2] Lim, T.K. (2012). Edible medicinal and non-medicinal plants volume 2: Fruits. Dordrecht Heidelberg New York London: Springer. Volume 2. P. 21-28.

[3] Anonymous. (2015). Medicinal Herbs and Plants Database: Malaysian Herbal Monograph (Garcinia atroviridis Griff. x. T. Anders.). In

http://www.globinmed.com/index.php?option=com_content\&view=article\&id=105957:garcinia-atroviridisgriff-ex-t-anders\&catid=209\&Itemid=143\#ag $\underline{2}$ (accessed on : $1^{\text {st }}$ March 2017)

[4] Roongpisuthipong, C., Kantawan, R., Roongpisuthipong, W. (2007). Reduction of adipose tissue and body weight: Effect of water soluble calcium hydroxycitrate in Garcinia atroviridis on the short term treatment of obese women in Thailand. Asia Pacific Journal of Clinical Nutrition, 16(1), 25-29.

[5] Zamree, M. S., Hada Masayu, I., Noor Rasyila. M. N., Abdull Rashih, A., Mohd Shahidan, M. A., Ong, B. K., Mohd Faizal, K., \& Rasadah, M. A. (2008). Concentration of hypdoxyxitric acid in Garcinia atroviridis (asam gelugor) fruits collected from different sites. In: Proceeding Plant Health and Man - Past, Present and Future. Forest Research Institute Malaysia.

[6] Antony C., D. A review of Asam Gelugor (Garcinia atroviridis) Griff. ex T. Aders. Dweck Data. p (1-4).

[7] Morat, P., Jalifah, L., Satirah, Z. A., Norhayati A.H. (2003). Physiological effects of Garcinia atroviridis extracts on rat blood pressure. In: The $7^{\text {th }}$ symposium of applied biology, Seri Kembangan, BMBH001.

[8] Li O. C., Wan, Y. H., Boon, K. B., \& Swee, K. Y. (2013). Updates on antiobesity effect of Garcinia origin (-)HCA. Evidence-Based Complementary and Alternative Medicine. Vol 2013 P.1-18.

[9] Tee, E. S., Noor M. I., Azudin M. N., Idris K. (1997). Nutrien composition of Malaysian food, $4^{\text {th }}$ ed. Institute Medical Research, Kuala Lumpur, p 299. 
[10] British Pharmacopoeia Commission. (2011). Appendix XVI: F. Microbiological Examination of Herbal Medicinal Products for Oral Use. In: British Pharmacopoeia Commission. British Pharmacopoeia 2011: volume $V$. London: TSO.

[11] National Pharmaceutical Control Bureau, Ministry of Health, Malaysia. (2015). Drug Registration Guidance Document (DRGD), First Edition-January 2013, revised July 2015.

[12] Nurhazwani, M. H., Saidatul Husni, S., Nor Azah, M. A., Azrina, A., Mailina, J., Norulaiman, Y., Wan Nurhafisya M., Mohammad Faridz Z. P. (2015). Quality Control of Zingiber officinale Oils in Product Formulations. Jurnal Teknologi (Sciences and Engineering), 77(3), 39-42. 